\title{
Semi-Presidential Systems: Dual Executive And Mixed Authority Patterns
}

\author{
Matthew Søberg Shugart \\ Graduate School of International Relations and Pacific Studies, University of California, San \\ Diego, USA. \\ E-mail: mshugart@ucsd.edu
}

Maurice Duverger in 1980 advanced the concept of a 'semi-presidential' regime: a mix of a popularly elected and powerful presidency with a prime minister heading a cabinet subject to assembly confidence. We can understand the performance of these regimes through a neo-Madisonian perspective that stresses agency relations between institutional actors. Executive and legislature as separate agents of the electorate - as in presidentialism - necessitates transactional interbranch relations. Fusion of powers - as in parliamentarism - means an executive that is hierarchically subordinated to the legislature. The dual executive of a semipresidential system mixes a transactional executive-legislative relationship with a hierarchical one. The advantages of this perspective include allowing delineation of semi-presidentialism from other hybrids, highlighting subtypes (premierpresidential and president-parliamentary) according to variations in the locus of transactional and hierarchical institutional relationships, and predicting which observed relationships between actors derive from relatively immutable constitutional features and which from more transitory features such as partisan alignments.

French Politics (2005) 3, 323-351. doi:10.1057/palgrave.fp.8200087

Keywords: executive-legislative relations; semi-presidential system; dual executive; premier-presidential system; president-parliamentary system; separation of powers

\section{Introduction}

Since it was first proposed by Maurice Duverger, the notion of a democratic regime type that can be characterized as semi-presidential has become well established. Given the substantial growth in the past quarter century of a distinct subfield devoted to the analysis of executive-legislative relations, ${ }^{1}$ and the proliferation of new constitutions after the fall of the Communist bloc, it is worthwhile to take stock of the theory and practice of Duverger's 'new political-system model.' Many new constitutions - not only in the region extending from Central Europe to Central Asia, but also in Africa - could be characterized as semi-presidential, yet there are important distinctions among 
them that need to be understood precisely as further analytic work proceeds. My goal in these pages is to return to Duverger's original conception and ground it more firmly in theoretical traditions in comparative constitutional design stretching back to theorists such as James Madison and Walter Bagehot, and then to turn to the contemporary empirical record and see how these traditions are reflected in the practice of semi-presidential systems.

Adapting from Duverger's (1980) original and influential definition, semi-presidentialism may be defined by three features:

A president who is popularly elected;

The president has considerable constitutional authority;

There exists also a prime minister and cabinet, subject to the confidence of the assembly majority.

These features define a dual executive (Blondel, 1984), in that the elected president is not merely a head of state who lacks political authority, ${ }^{2}$ but also is not clearly the 'chief' executive, because of the existence of a prime minister who may not be strictly a subordinate of the president. The precise relationship of the president to the prime minister (and cabinet), and of the latter to the assembly vary widely across regimes that fit the basic Duvergerian conception of semi-presidentialism, and these formal institutional variations are likely to have significant consequences for the behavioral performance of different systems.

By virtue of its being called semi-presidential, the regime type in question is clearly identified as a hybrid that is neither presidential nor parliamentary. If we consider 'presidential' and 'parliamentary' to be terms denoting pure types, from both of which semi-presidentialism draws certain characteristics, we need clear benchmarks as to the features of the pure types.

A 'pure' parliamentary democracy should be understood to mean a regime that can be defined by the following two basic features:

Executive authority, consisting of a prime minister and cabinet, arises out of the legislative assembly;

The executive is at all times subject to potential dismissal via a vote of "no confidence' by a majority of the legislative assembly.

These two criteria express a hierarchical relationship of executive to legislative authority, whereby the executive arises from and is responsible to the majority of the assembly. Presidential democracy, on the other hand, is defined by the following three basic features:

The executive is headed by a popularly elected president who serves as the 'chief executive'; 
The terms of the chief executive and the legislative assembly are fixed, and not subject to mutual confidence;

The president names and directs the cabinet and has some constitutionally granted lawmaking authority.

The defining characteristics of parliamentary and presidential democracy, then, speak first to the question of the origin and survival of the executive and legislative branches (Shugart and Carey, 1992). In a parliamentary system, executive authority originates from the assembly. The precise institutional rules for determining who shall form a cabinet vary from one parliamentary system to another, but for a system to be parliamentary, the process of forming a government must fall to the majority party, if there is one. If there is not, it must derive from bargaining among those politicians with an elective mandate from the most recent assembly elections. Once formed, the government survives in office only so long as it does not lose the 'confidence' of the majority.

In a presidential system, on the other hand, the origin and survival of executive and legislative authority are separate. The first criterion of the definition of presidentialism contrasts starkly with that for parliamentarism, in that it denotes the existence of a chief executive whose authority originates with the electorate. The second criterion specifies that, unlike in a parliamentary system, the chief executive is not subject to dismissal by a legislative majority. Furthermore, neither is the assembly subject to early dissolution by the president. $^{3}$ Both branches thus survive in office independent of one another. The addition of the third criterion, regarding the president's authority, is important for establishing the independence of the president not only in terms of origin and survival, but also in the executive function, for it sets out that the cabinet derives its authority from the president and not from parliament. It further stipulates that the president has some legislative authority, and thus is not 'merely' the executive. It is the fact of separate origin and survival combined with shared lawmaking powers that generates the necessity for the executive and legislature to bargain with one another, such that legislative change is a joint product of both elected branches.

\section{Hybrids: Mirrors and Mixes}

If we think of parliamentary and presidential government as Weberian ideal types, we must acknowledge that there are numerous regimes that contain some elements of one and some elements of the other, and are thus hybrids. However, not all combinations of these elements qualify a regime as 'semipresidential,' unless that term is nothing more than a synonym for 'hybrid.' If it is to denote a specific class of hybrids, then we should allow for the existence of 


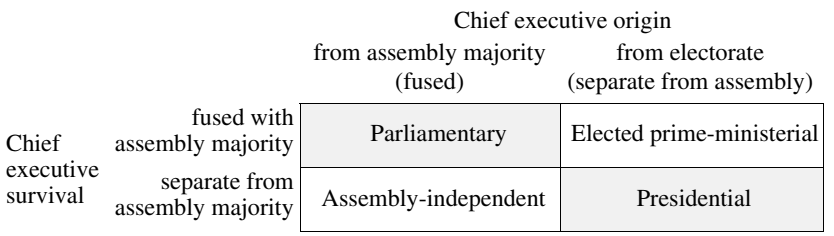

Pure types are shaded; their mirror hybrids are in the non-shaded cells.

Figure 1 Pure types of executive-legislative structure and their mirror hybrids.

other hybrids that might perform quite differently from a system with a popularly elected non-ceremonial president and an assembly-dependent cabinet.

Figure 1 shows the pure types and two logical (albeit rare) hybrids, based on the dimensions of origin and survival of executive authority vis-à-vis the legislative assembly. ${ }^{4}$ On each dimension we can dichotomize the relationship to the assembly as fused or separated. Fusion of origin means that the executive emerges from the assembly majority, whereas separate means it has its own fount of democratic accountability, that is, popular election. On the dimension of survival of the authority of the executive, fusion means that if the assembly majority breaks apart, the executive falls, whereas separation means that the executive serves out a term in office regardless of shifting majorities within the assembly. These are fundamental distinctions between regime types in the structure of authority, and the commonly recognized pure types have the same relationship on each dimension. Parliamentary systems occupy the fused-fused cell, while presidential systems occupy the separated-separated cell.

The 'off' diagonal of Figure 1 shows regimes that combine the two dimensions in the opposite way. In the upper right, with separated origin but fused survival, we have elected prime-ministerial government, in which the head of government is popularly elected, yet, along with his or her cabinet, is subject to ongoing confidence of the assembly majority. ${ }^{5} \mathrm{~A}$ hybrid of this sort has been employed only for a few years in Israel, but has been proposed in many other countries (Maddens and Fiers, 2004). The other hybrid of these two dimensions contains the opposite combination, fused origin and separate survival. This form, which can be termed an assembly-independent regime, is best represented by the Swiss case, although there have been other examples at various times, including Bolivia. ${ }^{6}$

Both of the hybrids depicted in Figure 1 are rare, yet they are really the truest hybrids in that they simply combine origin and survival in ways that mirror the combination in the pure presidential and parliamentary types. A semi-presidential system, on the other hand, is a mix rather 
than a mirror, because of its dual executive. Rather than simply combining the two dimensions of origin and survival in the opposite manner form the pure types, or being located somewhere in between them on a continuum, a semi-presidential system actually takes from both of the pure types. One portion of this dual executive - the president - has both origin and survival separated from the assembly, while the other portion - the prime minister (and cabinet) - has its survival fused with the assembly majority. As we shall see below, semi-presidential systems vary in the origin of the prime minister, but usually involve considerable separation from the assembly in this stage. The key point is that semi-presidential systems mix elements of the two pure types for each portion of a dual executive structure.

For the sake of conceptual continuity and clarity, then, it would be advisable to reserve the term, semi-presidential, for only those regimes that fit the three Duvergerian institutional criteria. Thus one should not, in my view, label as semi-presidential those systems in which: individual ministers may be removed from office by the assembly but there is no prime minister to coordinate assembly control over the cabinet (e.g. Colombia); or where a prime minister, but not the cabinet as a whole, can be removed by the assembly (e.g. Argentina); or where there is a prime minister but no provision for a binding vote of no confidence (e.g. South Korea). ${ }^{7}$ Each of these examples has fundamentally separated executive survival and should be seen simply as minimally attenuated forms of presidentialism.

Nor should semi-presidential systems be seen as alternating between presidential and parliamentary ideal types, as both Duverger $(1980,186)$ and Lijphart (1999, 121-122) have argued. ${ }^{8}$ I will address this point more fully below, but for now simply note that characterizing France or any other semipresidential system as alternating between each of the pure types is to define regime types by their behavioral outcomes, rather than by their institutional design. Either approach is justifiable, but the two should not be conflated. An institutional approach defines the authority patterns of the executive and assembly and how they are constitutionally related to one another. A behavioral approach, on the other hand, focuses on extra-constitutional factors such as the party system and leadership dynamics. To put it another way, the institutional approach advocated here allows us to predict how changes in the dynamics of partisan competition, for example, would be filtered through unchanged constitutional structures to produce changed behavior; a behavioral approach, on the other hand, starts with the observed behavior and may even assume away the constitutional structure. If it does not assume it away, then how can the same constitutional structure sometimes be 'presidential' and other times be 'parliamentary'? It cannot; rather, a semipresidential system always mixes features of both. 


\section{Patterns of Executive and Assembly Authority Relations: Hierarchies and Transactions}

The basic theoretical underpinning of presidentialism has its origins in The Federalist Papers, and here I will argue that the theory of constitutional design propounded by James Madison therein provides a basis for comparing semipresidentialism to both of the pure types. The key idea of the Federalists is to characterize political systems by how they channel political ambition. Like contemporary rational-choice institutionalists, Madison took it as axiomatic that political actors are motivated by personal gain. He accepted selfish motivation as inevitable and sought to harness it for the greater good. Doing so, he argued, entailed establishing a system of institutions that structure and check that ambition. Thus, Madison wrote in Federalist 51, the design of government 'consists in giving to those who administer each department (i.e. branch) the necessary constitutional means and personal motives to resist encroachments of the others' (Hamilton et al., 1787/1937, 337).

Ambition is checked, in the Federalists' design, through the creation of distinct branches with separate agency. That is, in what contemporary social science would recognize as a principal-agent conception of the delegation of authority, ${ }^{9}$ Madison, in Federalist 10, emphasized that any power delegated to representatives has the potential to be turned against the principal. Therefore, Madison argued, multiple competing agents of the citizenry must each be empowered and motivated to check the ambitions of one another. This is an alternative to a model based primarily on hierarchy. Contemporary scholarship in a neo-Madisonian tradition (Carroll and Shugart, 2005) is interested in the organization of government in terms of the hierarchical and transactional authority patterns between institutions. In a hierarchy, one institution is subordinated to another. Hierarchy is thus about vertical relationships, in that one actor is superior to another. Transactional relationships, on the other hand, are among co-equals. Two institutions or actors in a transactional relationship each have independent sources of authority, and must cooperate to accomplish some task, thereby implying a horizontal juxtaposition of co-equals. The neo-Madisonian perspective, as I use it here, specifies the formal hierarchical and transactional juxtaposition of authority between constitutionally defined actors. It then allows for the incorporation of informal or extra-constitutional features that shape the actual behavioral patterns, such as the structure of the party system and the preferences of officeholders, which might temper a formal transaction with elements of hierarchy or vice versa. By analyzing patterns of both formal authority and behavior, we can gain a firmer grasp on which features of regime performance are largely immutable (absent institutional reform) and which are transitory (dependent on election outcomes and leadership). 


\section{Authority patterns in presidential and parliamentary government}

The two pure types of institutional design — parliamentary and presidential are almost perfectly opposed to one another in terms of hierarchies and transactions. As a result of the fusion of origin and survival discussed above, a parliamentary system makes the executive an agent of the assembly majority, hierarchically inferior to it because the majority in parliament selects the executive and may terminate its authority. A presidential system, on the other hand, features an assembly and executive that originate and survive separately from one another, and thus must transact, because neither selects the other and neither may terminate the authority of the other.

Walter Bagehot $(1867 / 1963,14)$, in his classic work, The English Constitution, recognized the emergence of the hierarchy between the executive and legislative assembly when he noted that the cabinet had replaced the monarchy as the 'efficient' portion of government. Parliament, on the other hand, essentially had become an 'electoral college' that chose the government, but did little else because it had surrendered effective legislative authority to the cabinet. Bagehot explicitly contrasted the English system of 'Cabinet Government' with the American system, where:

... the President is elected from the people by one process, and the House of Representatives by another. The independence of the legislative and executive powers is the specific quality of the Presidential Government, just as the fusion and combination is the precise principle of Cabinet Government (Bagehot, 1867/1963, 14).

With this passage, then, Bagehot captures the essence of the distinction between parliamentarism and presidentialism: fused origin and survival leading to interbranch hierarchy in parliamentarism $v s$ separate origin and survival leading to interbranch transactions in presidentialism. The American and British systems remain iconic in the comparative literature on executive structure (Moe and Caldwell (1994), and Palmer (1995), are two recent examples), notwithstanding that neither country really typifies the larger universe of presidential and parliamentary systems. ${ }^{10}$ For instance, the spread of proportional representation across most of the European continent by early in the 20th century meant that parliamentary systems developed a distinct transactional flavor on account of coalition rather than single-party majority cabinets. Nonetheless, these transactions are primarily between the parties that form the coalition, rather than between executive and legislative institutions, per se. The hierarchical subordination of the cabinet to the assembly remains fundamental, given the requirement that the cabinet maintain the majority's 'confidence.' Lijphart (1984) has referred to this transactional nature of multiparty parliamentary systems as an 'informal separation of powers.' 


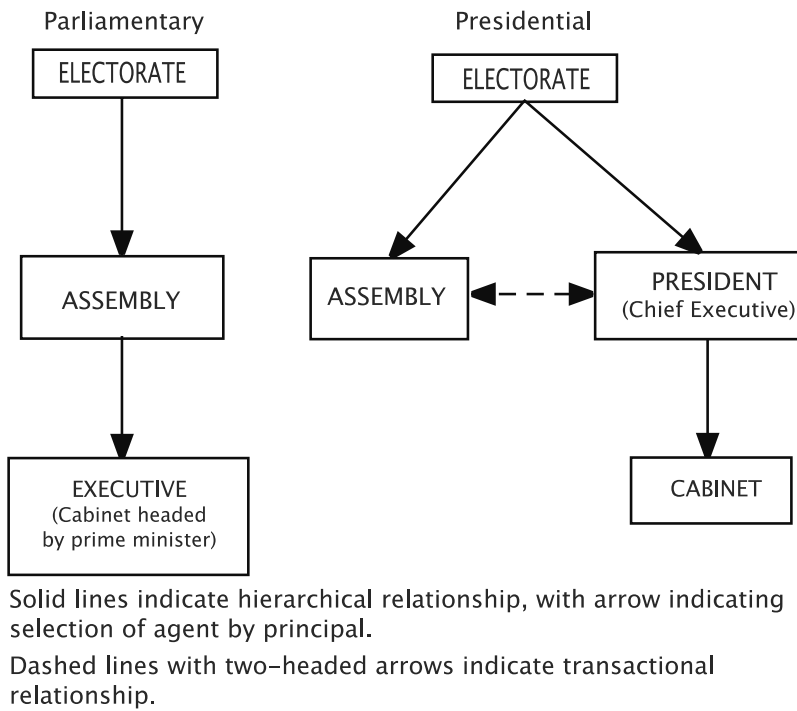

Figure 2 Hierarchical and transactional relations in the 'pure' forms of executive-legislative structure.

Likewise, in presidential systems outside the US, various forms of informal hierarchical relationships often develop between the executive and assembly, resulting from the president's position as head of a majority party or congressional coalition. These hierarchical partisan or coalitional relationships within presidential systems could be said to generate an 'informal fusion of powers,' notwithstanding the formal separation of the origin and survival of the executive and legislative institutions (Shugart, 2007). Thus in either pure type, behavioral practice originating from the constellation of political parties may temper the institutional authority patterns.

Leaving aside these behavioral departures from the pure institutional structure, we can depict the authority relationships as in Figure 2. The formal structure of executive-legislative relations in the parliamentary system is depicted as having a hierarchical chain of delegation, and no transactional relations. Voters select (delegate to) a legislature, and the legislature selects (delegates to) the executive. ${ }^{11}$ The political process of the presidential system is depicted with separate delegation links from the electorate to the assembly and the popularly elected executive; additionally, there is a transactional relationship between executive and assembly, which engage in a horizontally depicted process of interbranch transactions. The only clear hierarchical relationship among institutions is between the president and his or her cabinet, which is appointed by and serves at the pleasure of the president. ${ }^{12}$ 
As we shall see, the authority relations in semi-presidential systems are much less straightforward than in the pure types, which is precisely what makes them not suitable for inclusion into a simple typology like the one in Figure 1, above. When we turn to semi-presidentialism, not only are there the informal behavioral relationships that may temper or partly contradict the formal institutional relationship - as is the case in the actual performance of any constitutional structure — but also the formal relationships themselves are more complex. Owing to the dual nature of the executive, the executive's relationship to the assembly may contain mixtures of both transaction and hierarchy. In the next section, I will review briefly the theoretical justification given for such mixed patterns of formal authority, before disaggregating the concept of semi-presidentialism more fully, which I argue is needed in order to make sense of differences in actual performance across such systems.

\section{Authority patterns in semi-presidential government}

The juxtaposition of an elected president with a cabinet responsible to parliament is the hallmark of a semi-presidential system. This combination was placed in the German Weimar constitution on the advice of the eminent social scientists Hugo Preuss, Robert Redslob, and Max Weber (Mommsen, 1985; Meyerson, 1999; Stirk, 2002). Weber (1917/1978, 1452-1453) mistrusted parties and believed that the 'plebiscitary' selection of the president would force parties 'to submit more or less unconditionally to leaders who held the confidence of the masses.' By this phrase, Weber is calling for an agent of the electorate to serve as a check on the electorate's other agents, members of a parliament organized into multiple political parties.

Redslob (1918), on the other hand, was an advocate of what he called 'authentic parliamentarism' on the British model, where there exists a parliamentary opposition capable of assuming the government. Preuss, as summarized by Stirk $(2002,514)$, justified Weimar's synthesis of these concepts as follows: The constitution would provide for a president and parliament, each with 'an autonomous source of legitimacy.' This notion of separate legitimacy can be seen as a modern echo of Madison's call for separate agency as a means of keeping each institution in its proper place. Yet the Weimar synthesis retained cabinet responsibility to parliament. Such is the very essence of a semi-presidential system.

The subsequent collapse of the handiwork of these German social scientists in the rise of Adolf Hitler has largely discredited their work as the theoretical foundation of contemporary semi-presidential government. Nevertheless, the Weimar founders' desire for regimes that combine at once a popularly legitimated and more-than-ceremonial president with a cabinet that can be replaced if it loses the confidence of the voters' other agents in the assembly 
remains powerful among constitutional designers today. However, nowadays semi-presidentialism is more closely identified with France and with Charles de Gaulle's call, in his Bayeux Manifesto of 1946, for a 'chief of state, placed above the parties.' There can be little doubt that the political stability that was generated under the Fifth Republic following the instability of the Fourth Republic is a major source of the appeal of semi-presidentialism today. In that context, it is somewhat ironic that de Gaulle actually suggested that the president he envisioned be 'elected by a body which includes the parliament but which is much larger' (excerpted in Lijphart, 1992, 140-141). Only with his plebiscite in 1962 did de Gaulle establish direct election of the French president and thereby create what has become the most famous and emulated semipresidential system in the world. As I shall show, however, many of the emulators have borrowed rather selectively from the French model, such that some semi-presidential constitutions have rather different logics of hierarchy and transaction with respect to the relationship of the cabinet to the two elected institutions. ${ }^{13}$

The practice of semi-presidentialism has been quite diverse, as Duverger (1980) noted, both in formal constitutional powers and in actual behavior.
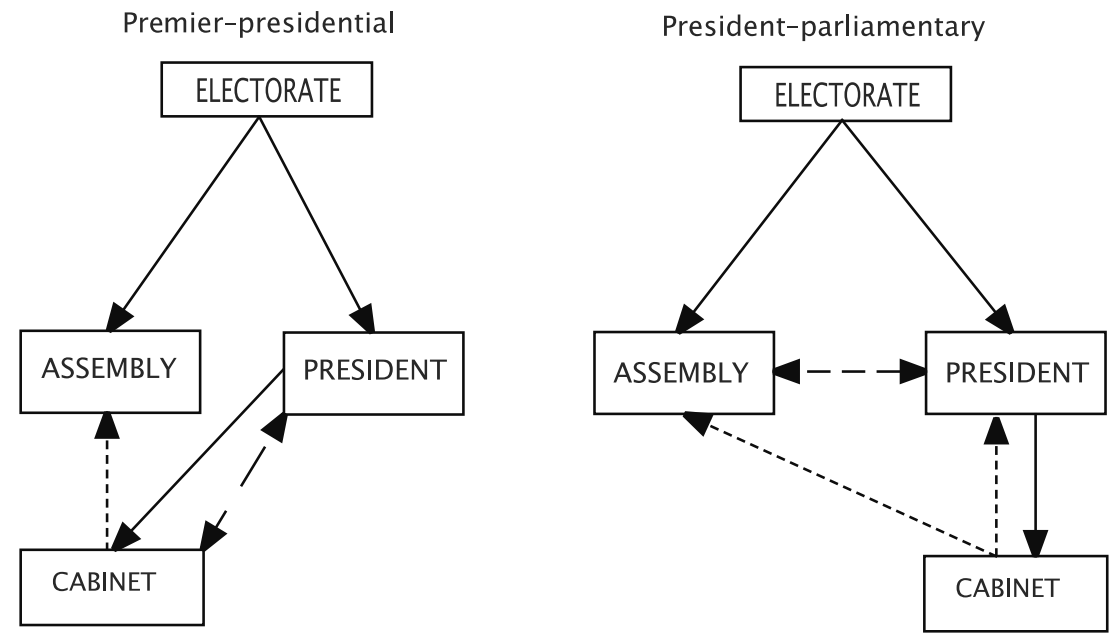

Solid lines indicate hierarchical relationship, with arrow indicating selection of agent by principal.

Dotted lines indicate hierarchical relationship, with arrow indicating accountability of agent to principal who may terminate delegated authority.

Dashed lines with two-headed arrows indicate transactional relationship.

Figure 3 Hierarchical and transactional relationships in the two main forms of semi-presidential systems. 
Some presidents that appear quite powerful on paper are actually observed to exercise few powers (e.g. Austria), while others seemingly have limited formal powers, yet can be dominant political players (e.g. France). Under the rubric of semi-presidentialism, there is much variation, both institutionally and behaviorally. This is why Shugart and Carey (1992) proposed a further subdivision of the concept into premier-presidential and president-parliamentary subtypes: Under premier-presidentialism, the prime minister and cabinet are exclusively accountable to the assembly majority, while under presidentparliamentarism, the prime minister and cabinet are dually accountable to the president and the assembly majority. This distinction has not always been appreciated in the literature, and has been criticized on various terms by Sartori (1994a) and Siaroff (2003). Nonetheless, I hope to show here that the distinction captures a meaningful dimension of variation.

Figure 3 shows the authority patterns of two stylized semi-presidential systems, one in which the cabinet is exclusively accountable to the assembly (premier-presidential) and the other in which it is dually accountable (president-parliamentary). The complexity of the formal institutional relationships is immediately apparent. In fact, it is necessary to introduce an additional graphical device to show the flow of authority in these systems. In the pure types depicted in Figure 2, relationships of accountability — best understood as boiling down to who can dismiss an agent - are simply the reverse of the selecting (delegating) relationship. Thus in a parliamentary system the assembly (or more accurately in actual practice the party or parties comprising the majority) selects the cabinet and also may dismiss it. In a presidential system, the president both selects and may dismiss the cabinet. In semipresidential systems, on the other hand, a key feature is that the institution that selects an agent may not be the same one empowered to dismiss that agent. The Duvergerian definition of semi-presidentialism, which I have adhered to here, is vague on this very important point because it does not define what the 'considerable' powers of the president are. The subtypes that Shugart and Carey introduced define whether those powers include the all-important right to dismiss a cabinet that enjoys parliamentary confidence.

Thus in a typical premier-presidential system, the president selects the prime minister who heads the cabinet, but authority to dismiss the cabinet rests exclusively with the assembly majority. The fact that a president in such a system cannot guarantee that his or her preferred cabinet can remain in place is both what separates these systems from pure presidential systems and is a feature that restricts the president's real choice of prime-ministerial candidate to someone he expects to be able to command parliamentary support (or at least acquiescence). Once appointed then, a cabinet that enjoys parliamentary confidence is not subordinated to the president but to parliament, and thus the relationship between president and cabinet is strictly speaking transactional. It 
is depicted as such in the left panel of Figure $3 .{ }^{14}$ In behavioral practice, the cabinet may be subordinated to the president if: (1) the president and the assembly majority come from the same side of an ideological divide, and (2) the president is the de facto head of his or her party. These conditions have been approximated in various periods in France, especially before 1986, thus accounting for the observation that French government often has been 'presidential' in character. These patterns of presidential relationship to the party system cannot be accounted for by an institutional definition. What an institutional definition allows us to recognize is that it is precisely the relationship of the president to the constellation of parties in the assembly that is critical for determining the extent of presidential dominance, given that, institutionally, a premier-presidential system subordinates the cabinet to the assembly.

In a typical president-parliamentary system, on the other hand, the president selects the cabinet and also retains the possibility of dismissal. In this sense, this form of semi-presidentialism is much closer to pure presidentialism and is the reason why the figure places the cabinet beneath the president, in contrast to the depiction of premier-presidentialism. Nonetheless, these systems are semi-presidential because the assembly majority may dismiss the cabinet even if the president would prefer to retain it. Thus the president and assembly must engage in transactions, as shown in the figure, but unlike in pure presidential systems these transactions are not only over policy-making. They are ongoing transactions over the composition and direction of the cabinet, brought on by the dual accountability that defines the president-parliamentary subtype.

The figure does not introduce the possibility of dissolution of the assembly by the president, because the basic definition of semi-presidentialism or its subtypes does not require that such power be present (or absent). Nonetheless, dissolution clearly is a quite considerable power, and it is worth thinking about how its existence affects the mix of hierarchy and transaction. Technically speaking, the presence of dissolution power does not make the system more 'presidential' because presidentialism by definition means separation of not only origin but also survival. Only if the assembly may remain in office independent of the preferences of the president (and vice versa) can the institutional relationship between them be the purely transactional form that the regime type calls for and Madison spelled out in the Federalist Papers. However, despite breaking separation of survival, dissolution provides a Madisonian (and also, as noted above, Weberian) logic within a semipresidential system: it is a means of reinforcing the president's ability to serve as a check on the assembly and its parties. It thus makes sense in the context of a system in which the president is denied full control over the cabinet on account of the provision for a prime minister subject to parliamentary 
confidence. In other words, presidential power of dissolution provides a counterweight to the assembly's enhanced authority. ${ }^{15}$

Specifically, then, if the president possesses dissolution power, it provides another instance by which one principal in a semi-presidential system may select an agent, but that agent must consider the preferences of a different institution empowered to terminate its authority. Under those semi-presidential system that have a dissolution provision, the president may decide when the voters will choose new legislative agents. As a result, the assembly parties comprising the majority must consider the preferences of the (usually) broader constituency that empowered the president separately from the process by which voter preferences were aggregated through the assembly electoral system. Dissolution is thus parallel to the defining characteristic of semipresidentialism by which the assembly may dismiss the head of the executive branch notwithstanding that it was the voter's other agent (the president) who initiated the appointment of the incumbent cabinet. ${ }^{16}$

\section{Semi-Presidentialism in Practice}

The precise balance of hierarchy and transaction between the two elected branches and between the president and cabinet in semi-presidential systems can vary nearly infinitely, even if we confine ourselves to the formal relationships. It is this variability that has led to controversy in defining what a semi-presidential system is, and has led some to argue against the value of the subtypes I have articulated here. Nonetheless, I hope to show that there is a clear divide between these two subtypes, and that this division has important behavioral and performance implications once we situate the formal features into the party-system constellations in which they operate. Before considering the role of parties in the behavior of premier-presidential and presidentparliamentary systems, it would be useful to consider which actual cases fall into the respective subtypes.

\section{Variations among semi-presidential constitutions}

Table 1 summarizes several semi-presidential democracies ${ }^{17}$ by asking a series of questions regarding the relation of the president and prime minister to one another and to parliament. For each question, a 'yes' means greater authority for the president. Two questions are especially critical to the differentiation of subtypes of semi-presidentialism: Whether the president has discretion to dismiss a prime minister and cabinet, ${ }^{18}$ and whether the assembly is restricted in voting no confidence in a cabinet. ${ }^{19}$ As can be seen immediately, the systems classified as premier-presidential all have an indication of 'no' for both of these 


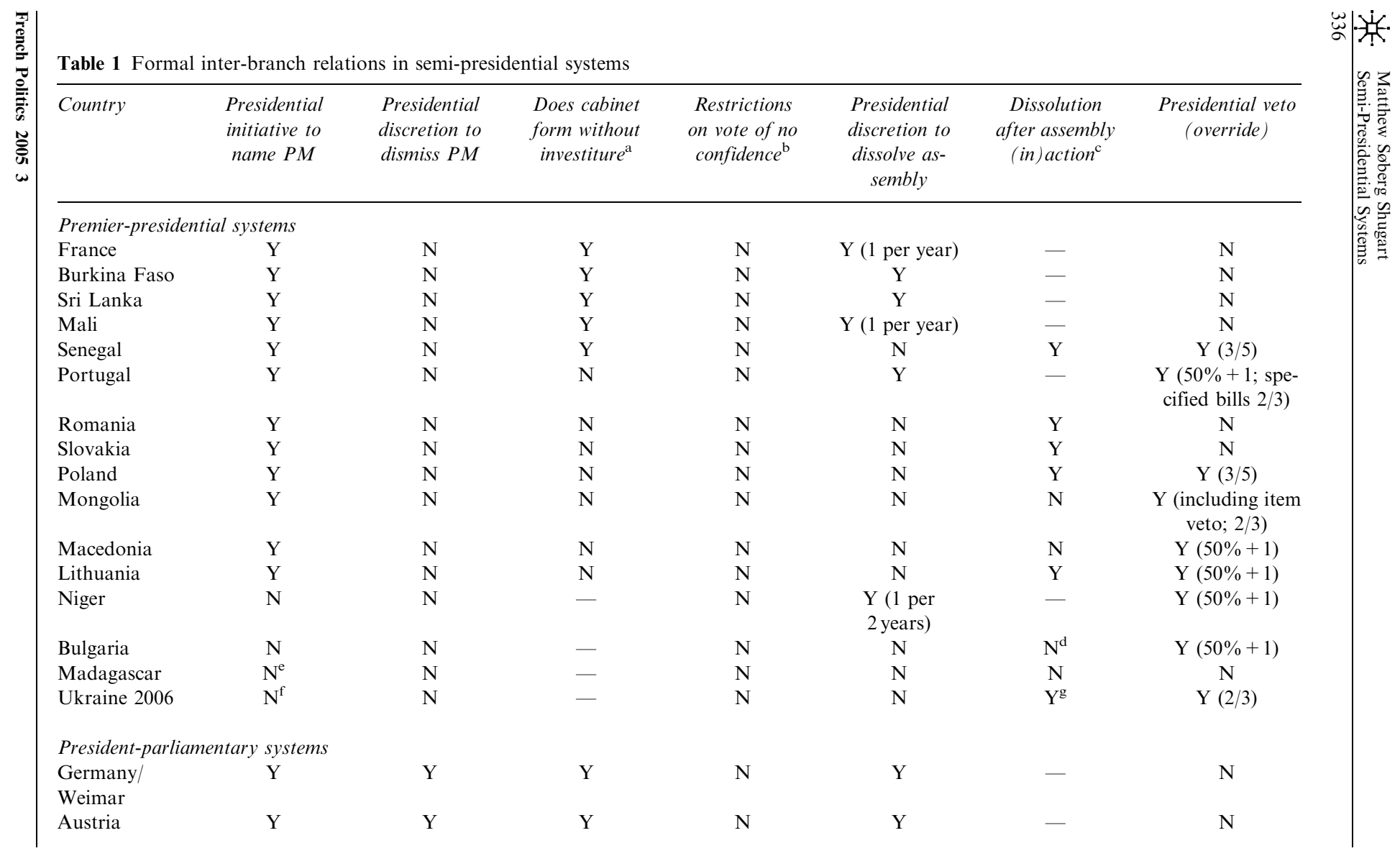


Table 1 (Continued)

\begin{tabular}{|c|c|c|c|c|c|c|c|}
\hline Country & $\begin{array}{c}\text { Presidential } \\
\text { initiative to } \\
\text { name PM }\end{array}$ & $\begin{array}{l}\text { Presidential } \\
\text { discretion to } \\
\text { dismiss PM }\end{array}$ & $\begin{array}{c}\text { Does cabinet } \\
\text { form without } \\
\text { investiture }^{\mathrm{a}}\end{array}$ & $\begin{array}{l}\text { Restrictions } \\
\text { on vote of no } \\
\text { confidence }^{\mathrm{b}}\end{array}$ & $\begin{array}{l}\text { Presidential } \\
\text { discretion to } \\
\text { dissolve as- } \\
\text { sembly }\end{array}$ & $\begin{array}{l}\text { Dissolution } \\
\text { after assembly } \\
\text { (in) action }{ }^{\mathrm{c}}\end{array}$ & $\begin{array}{c}\text { Presidential veto } \\
\text { (override) }\end{array}$ \\
\hline Namibia & $\mathrm{Y}$ & $\mathrm{Y}$ & $\mathrm{Y}$ & $\mathrm{N}$ & $\begin{array}{l}\text { Y (triggers } \\
\text { new pres. } \\
\text { election) }\end{array}$ & & $\mathrm{Y}(2 / 3)$ \\
\hline Mozambique & $\mathrm{Y}$ & $\mathrm{Y}$ & $\mathrm{Y}$ & $\mathrm{N}$ & $\mathrm{N}$ & $\mathrm{Y}$ & $Y(2 / 3)$ \\
\hline Armenia & $\mathrm{Y}$ & $\mathrm{Y}$ & $\mathrm{N}$ & $\mathrm{N}$ & Y (1 per year) & - & $\mathrm{N}$ \\
\hline Peru & $\mathrm{Y}$ & $\mathrm{Y}$ & $\mathrm{N}$ & $\mathrm{N}$ & $\mathrm{N}$ & $\mathrm{Y}$ & $\mathrm{Y}(50 \%+1)$ \\
\hline Russia & $\mathrm{Y}$ & $\mathrm{Y}$ & $\mathrm{N}$ & $\mathrm{Y}$ & $\mathrm{N}$ & $\mathrm{Y}$ & $\mathrm{Y}(2 / 3)$ \\
\hline Ukraine 1996 & $\mathrm{Y}$ & $\mathrm{Y}$ & $\mathrm{N}$ & $\mathrm{Y}$ & $\mathrm{N}$ & $\mathrm{Y}^{\mathrm{g}}$ & $\mathrm{Y}(2 / 3)$ \\
\hline Georgia & $\mathrm{Y}$ & $\mathrm{Y}$ & $\mathrm{N}$ & $\mathrm{Y}$ & $\mathrm{N}$ & $\mathrm{Y}$ & $\mathrm{Y}(3 / 5)$ \\
\hline Taiwan & $\mathrm{Y}$ & $\mathrm{Y}$ & $\mathrm{Y}$ & $\mathrm{Y}$ & $\mathrm{N}$ & $\mathrm{Y}$ & $Y(50 \%+1)$ \\
\hline
\end{tabular}

$\mathrm{Y}$, yes; $\mathrm{N}$, no

Within each category, the 'paradigmatic' case is listed first, and then countries are grouped in clusters ordered roughly by overall agreement with the basic regime type, in descending order.

Source: Author's coding of constitutions from http://confinder.richmond.edu/; except Niger (http://droit.francophonie.org/doc/html/ne/con/fr/ 1999/1999dfnecol.html); Taiwan (Noble, 1999); and Ukraine 2005 (Christensen et al., 2005).

${ }^{a}$ Deemed inapplicable in terms of an increment of presidential authority if president does not initiate the naming the PM.

${ }^{b}$ Meaning that president may ignore a vote of no confidence or the assembly is restricted as to when it may initiate such a vote.

${ }^{\mathrm{c}}$ Deemed inapplicable if president has discretion to dissolve independent of assembly (in)action.

${ }^{\mathrm{d}}$ Dissolution is automatic in the event a government cannot be formed.

${ }^{\mathrm{e}}$ If assembly fails to elect or approve the program of a government, the president appoints a prime minister who cannot be subject to a noconfidence vote till next ordinary session.

${ }^{\mathrm{f}}$ President retains initiative on ministers of defense and foreign affairs.

${ }^{\mathrm{g}}$ Also restricted to once per year. 
questions. All the president-parliamentary systems have 'yes' to the question of dismissal by the president, though they vary on the presence of restrictions on assembly-initiated dismissal (i.e. no confidence).

Within each category, the countries in Table 1 are grouped into clusters, with the first cluster headed by the 'paradigmatic' case schematized in Figure 3, above (France for premier-presidential, and Weimar for president-parliamentary). Then the subsequent clusters represent movement away from the mixed authority relationship that is the distinct feature of semi-presidentialism: the separation of selection and dismissal principals over the cabinet-agent. For instance, those premier-presidential systems in Table 1 beginning with Portugal generate a higher degree of parliamentary agency over government formation (in addition to dismissal), due to the requirement for investiture. Those listed from Niger on down are even more 'parliamentary' on account of the assembly's initiative in government formation. Among the president-parliamentary systems, those listed after the first four similarly reduce the separation of appointment and dismissal agency by involving both president and assembly in the initial formation of government and/or by reducing the agency relationship between parliament and the cabinet. The last case, Taiwan, is arguably the most 'presidential' on the account of the president's ability to form a government independently of the assembly along with the latter's restricted ability to vote no confidence. Thus for both subtypes of semipresidentialism, the last-listed cases are closer to one of the pure types (parliamentary or presidential, respectively) than they are to the defining authority relations of semi-presidentialism.

\section{Premier-presidential systems}

In a premier-presidential system, if the president does not have initiative in naming a premier, the regime is barely distinct from parliamentarism. However, even when the president has this initiative it may be almost meaningless if there is a partisan or coalitional majority that organizes the assembly. In such a case, the majority's unrestricted right to vote no confidence ensures hierarchical subordination of the cabinet to parliament. It is when elections have returned no clear majority, or a majority subsequently disintegrates, that the president may play a brokering role by strategically proposing the formateur most likely to form a government relatively compatible with the president's preferences. If there is also no requirement for investiture, then the president's leverage is further enhanced because the president may be able to put in office a government that is tolerated by a majority even if not actively supported by it (i.e. a minority government) ${ }^{20}$

Not surprisingly, the cluster of premier-presidential cases with maximal presidential initiative over prime-ministerial selection includes the most widely 
recognized contemporary case of semi-presidentialism, France, as well as several former French colonies. Sri Lanka is also included within this cluster. ${ }^{21}$ Seven cases of premier-presidentialism provide the president with initiative, but require investiture. These systems, which include Portugal and several postcommunist countries, somewhat reduce the discretion of the president over the cabinet, but otherwise maintain the separation of selection and dismissal authority. The remaining cases of premier-presidentialism are much closer to being parliamentary regimes in that the initiative for selecting a prime minister rests within the assembly majority, rather than with the president. In fact, the only reason these are not cases of parliamentarism with a figurehead president is that the president has at least one of the following additional powers: dissolution (as in Niger), a veto (as in Bulgaria and Ukraine 2006, as well as Niger), or the right to appoint a prime minister if the assembly majority deadlocks (Madagascar).

As can be seen in Table 1, 12 of the 16 cases allow the president to dissolve the assembly. In six of these, the president may do so on his or her own initiative (with restrictions on frequency), while in the others dissolution power can be exercised only in response to assembly behavior, that is, a vote of no confidence or failure to invest a new government. Presidents can be expected to exercise this authority only when they expect the voters to take their side in the disagreement and provide a fresh mandate to an assembly more sympathetic to the president than the one dissolved. Of course, presidents can miscalculate, as happened when conservative president Jacque Chirac in 1997 wound up with a Socialist-dominated assembly after a dissolution. When the majority expects the president to prevail after a dissolution, its mere threat can be a powerful bargaining chip for the president. Nonetheless, as the French example shows, it is the electorate that ultimately determines whether the president's bargaining authority is enhanced or diminished.

The final form of presidential authority indicated in Table 1 is veto power. Even if the president has no discretion in the forming of cabinets or the right to dissolve parliament, his or her constitutional authority can be regarded as 'quite considerable' in Duverger's sense if cabinet legislation approved in parliament can be blocked by the people's elected agent. ${ }^{22}$ Such powers are especially relevant if an extraordinary majority is required to override a veto, as in Mongolia, Poland, and Senegal. In these cases, while the government is fully accountable to parliament, it cannot legislate without taking the potentially different policy preferences of the president into account. Even if the veto override requires only an absolute majority $(50 \%+1$ of the total membership), the veto may result in a transactional situation that would not occur in a parliamentary system: the inability of a government to pass a law with a plurality while some parties or members either abstain or are absent from the vote. It is such a situation that is the sole feature 
that prevents Bulgaria from being a case of simple parliamentarism with a mere figurehead president. ${ }^{23}$

\section{President-parliamentary systems}

Turning to president-parliamentary systems, we have already established (by definition) that all of them explicitly mandate that the cabinet is responsible to both the president and the assembly. However, some of these systems place restrictions on the ability of the assembly to exercise no-confidence votes over the cabinet; those that do so are closer to being presidential systems because they enhance the separation of survival between the executive and assembly during any period in which the constitution prevents the majority from expressing its lack of confidence.

The first case listed is one of historical interest, the German Weimar Republic. It was the experience of this system that led Shugart and Carey (1992) to caution against president-parliamentarism, on the grounds that Weimar's configuration of powers gave too little incentive for bargaining. Each actor always retained the authority to postpone a resolution of political conflict by exercising unilateral powers. The president could appoint a government without assembly consent and dare the assembly to bring a no-confidence vote. Because there were no meaningful restrictions on the president's dissolution power, he could dissolve the assembly to pre-empt a no-confidence vote, maintain his preferred cabinet in office in the interim, and then still not acquiesce to the new majority because of his continuing discretion over cabinet appointment and dismissal. Surprisingly, Austria's constitution has provided for an almost identical configuration of formal powers since 1929 - surprising because the scholarly consensus is that actual practice is almost strictly parliamentary. Thus the Austrian case emphasizes the importance of understanding both formal powers and the configuration of the party system. As Müller (1999) notes, the combination of effective party control over recruitment of presidents, relatively stable voting behavior, and postwar power-sharing between the two major parties have kept presidents' actual freedom of maneuver sharply limited. Nonetheless, in a different party-system environment, Austria's formal provisions would imply presidents who could be very active in making and breaking governments, as well as seeking to hold parliamentary elections at times most convenient to the president.

Fortunately, none of the more recently established president-parliamentary constitutions has Weimar's (or Austria's) complete list of unilateral powers. Of the contemporary cases beyond Austria, only four provide the assembly majority an unrestricted right to vote no confidence, and of these, only two allow the president unrestricted authority to appoint the prime minister. These two, Mozambique and Namibia, thus resemble more closely than any other 
recently established constitutions the structure of authority depicted in the right panel of Figure 3, whereby the dual accountability of the cabinet to both the president and the assembly is maximized.

Several president-parliamentary regimes restrict the assembly's right to dismiss a cabinet: Georgia, ${ }^{24}$ Russia, Taiwan, and Ukraine (1996-2005). All of these except Taiwan also require the president's nominee for prime minister (or the entire government) to be confirmed by the assembly. And all of them restrict the presidential power of dissolution. Unlike the Weimar prototype of president-parliamentarism, then, these systems require a series of contingencies before either branch may threaten the survival of the other. Thus they should generate greater interbranch cooperation than the Weimar system. In Russia, for example, a no-confidence vote does not have immediate effect. If it is repeated within 3 months, then the president still has a choice: accept the resignation of the cabinet and nominate a new prime minister, or retain the cabinet but call a new election (which need not be for four months). As Morgan-Jones and Schleiter (2004) observe, the Russian configuration of powers induces bargaining tied to electoral expectations, and thereby 'reinforces the authority of the most recently elected branch of government' (p. 145), while Protsyk similarly emphasizes the 'symmetry' of parliamentary and presidential powers over the cabinet in Ukraine's 1996 constitution. ${ }^{25}$ As a result of these restrictions on unilateral action, these post-Soviet cases are the most 'presidential' of the systems shown in Table 1 in that they approximate the separate origin and survival of the pure presidential systems. They deviate from presidentialism only by providing mechanisms through which extended interbranch impasses can be potentially resolved by the president's acquiescence in a new cabinet that enjoys parliamentary confidence or else early assembly elections.

Table 1 shows that dissolution power as a presidential initiative is rare in the contemporary president-parliamentary systems. In fact, only in Armenia may the president dissolve (once per year) without a trigger (e.g. assembly failure to invest a government). Namibia allows the president to dissolve at any time but places a novel negative incentive on his exercise of the right: He must stand for a new election at the same time as the new assembly elections. Finally, in Table 1 we can see that most of the president-parliamentary systems provide the president with veto power, usually subject to three-fifths or two-thirds majority override. It is perhaps not surprising that president-parliamentary systems are more likely to give the president significant lawmaking power. In the sense that these systems operate on a more presidential logic by giving the president considerable leverage over the cabinet, they also align more closely with the pure presidential systems in giving the president a transactional role in the process of lawmaking. Here the Russian system goes a step farther, endowing the presidency with ample decree powers as well as a veto that is difficult to 
override (Parrish, 1998; Remington et al., 1998; Chandler, 2001), as does that of Ukraine (Protsyk, 2004). The premier-presidential systems, on the other hand, are more likely to have no or a weak veto, which is more consistent with their greater privileging of parliament in the empowerment of the executive.

\section{Parties, government, and opposition in the performance of semi-presidential systems}

It is clear from the foregoing overview that semi-presidentialism is not actually a coherent category to the same degree as parliamentarism or presidentialism; that is why it is useful to consider how its further subdivisions, premierpresidential and president-parliamentary, function differently. As with any regime type, interactions among political parties, as well as formal constitutional provisions, matter for system performance. ${ }^{26}$ This is perhaps most striking in the case of Austria, where convention has established an almost purely parliamentary regime (Müller, 1999). The French case, which has had alternations between two distinct blocs in the assembly, illustrates clearly the interaction of formal powers and the party system. Both Duverger (1980) and Lijphart (1999) have referred to France as 'alternating' between presidential and parliamentary phases. When the assembly is controlled by a sympathetic majority, the prime minister and cabinet are (de facto) subordinate to the president, but when the assembly majority is opposed to the president, the latter must yield to the assembly's preference for prime minister. This is certainly an accurate description of French alternation in government, yet to describe one of the phases as 'presidential' is misleading, because it obscures the fact that presidential-cabinet compatibility is dependent on the outcome of assembly elections. In a presidential system, on the other hand, the president appoints, dismisses, and conducts the affairs of the government regardless of the composition of the assembly. Indeed, that the French system remained more like the British, and hence more parliamentary, even under compatible governments, was recognized by King (1976). When split control of the assembly and president would subsequently occur, it became clear that in such a situation the opposition to the government is led by the president jointly with the assembly minority. This is in stark contrast to a presidential system like the US, where split controls places opposition in the hands of the assembly majority, because control of the cabinet remains in the hands of the president (Helms, 2004). ${ }^{27}$

The crucial distinguishing feature of premier-presidentialism is thus that the political complexion of the government is always compatible with the assembly whether or not it is simultaneously compatible with the president. Again this is a key distinction obscured by characterizing France as alternately presidential and parliamentary. ${ }^{28}$ A pattern similar to the French case of compatible 
majorities alternating with periods of cohabitation emerged in Lithuania, where Talat-Kelpsa (2001) notes that the ability of the Lithuanian president to influence government formation and policy declined abruptly when he lost the sympathetic majority in parliament. Yet in Taiwan, an opposition-dominated assembly lacked institutional mechanisms to force the president to change prime ministers, resulting in 'divided government' (Rigger, 2002) more akin to the US example, rather than French or Lithuanian-style cohabitation. Both Lithuania and Taiwan exhibit generally bipolar party systems resembling that of France, yet differences in the formal powers of the president over cabinets are decisive for regime performance. These differences are obscured by any definition of regime type based on the observed behavior, but are immediately clear when we consider the institutional relationships of president, assembly, and cabinet. That is, even before the emergence of split partisan control between the president and assembly, it is possible to predict continued presidential control of the cabinet if we know the system is institutionally president-parliamentary, or else a shift in the cabinet to alignment with the new assembly majority if the system is premier-presidential.

The French, Lithuanian, and Taiwanese examples all come from party systems that are fundamentally bipolar. If instead the structure of partisan competition is such that no clear majority-opposition divide emerges, the president is likely to have more de facto discretion under either semipresidential subtype. Further research on these systems is needed before we can arrive at a clear understanding of how different formats affect government formation/termination and policy-making. Roper (2002) suggests that with less developed party systems, cohabitation may induce instability in premierpresidential systems, ${ }^{29}$ whereas Morgan-Jones and Schleiter (2004) suggest that a president-parliamentary regime can be designed to induce cooperation between the president and assembly. If this proves correct, it would be almost opposite to my prior expectation, expressed in Shugart and Carey (1992), that president-parliamentary systems would almost necessarily be less stable. However, Carey and I concerned ourselves with the fully presidentparliamentary model of Weimar, and did not contemplate the more 'presidential' variants that have subsequently emerged in Russia, Taiwan, and elsewhere. Potentially these countries (i.e. those in the bottom half of the 'president-parliamentary' section of Table 1) contain a combination of powers well suited to weak party systems. For instance, in contexts where many major parties are 'clientelistic,' as Protsyk (2003) describes for Ukraine, presidentialassembly bargaining over cabinets takes the form of particularistic concessions that are more typical of (pure) presidential systems with weak parties. The nationally elected and powerful presidency may compensate for the relative absence of well-organized national parties that are needed for parliamentary (and perhaps premier-presidential) systems to function well. ${ }^{30}$ If this is 
accurate, then Ukraine's change in 2006 to premier-presidentialism - with the presidency stripped of discretion over the selection of a prime minister - will be a critical case, and its reforms actually could prove risky to political stability at least until such time as better organized national parties emerge. Developing further the nature of relationships between presidents, assemblies, and cabinets in both subtypes of semi-presidentialism and under different party-system characteristics should be a high priority in ongoing research on executivelegislative relations.

\section{Conclusion}

Duverger's (1980) essay marked the beginning of the acceptance of a new term, semi-presidentialism, in the comparative literature and also presaged the emergence of this 'new political-system type' as the dominant constitutional form for new democracies. By my count (see Shugart, 2007) there are 14 countries among the post-communist states that are democracies. Of these, 12 are semi-presidential in some form. ${ }^{31}$ There are 12 new democracies in Africa since 1980, and seven of them are semi-presidential. Only in Latin America have all new democracies retained a pure presidential form, except for Peru (president-parliamentary) and Bolivia (assembly-independent). Only among the former British colonies has there remained a strong preference for parliamentary systems, though a few have turned towards presidentialism (e.g. Ghana, Malawi, and Nigeria). Semi-presidentialism apparently is a regime type whose time has come. Yet as I have noted in this article, there still is nothing like a scholarly consensus on how to define it, nor a deep understanding of how variations within the type affect actual regime performance. In this conclusion, I hope to sketch a rough map of where we should be going in an effort to understand this regime type.

I have argued in favor of a strictly institutional definition that takes off from the definition used by Duverger: A popularly elected presidency with considerable powers alongside a prime minister and cabinet subject to parliamentary confidence. This is a simple definition for a complex regime type, and that is its appeal, as well as its limitation. This Duvergerian definition is appealing because it separates those regimes that have a dual executive with one executive official originating and surviving separately form the assembly and the other with its survival fused with the assembly — from other hybrids that contain a single clearly 'chief' executive. That is, it defines semipresidentialism as a mix of the principles of presidentialism and parliamentarism, rather than a simple recombination of them (see Figure 1).

The definition has limitations, however, in that it generates a regime 'type' that is not nearly as coherent as the simpler types, even if we confine ourselves 
only to the formal institutional structure of executive and legislative authority. By drawing on Madison's theorizing about transactions between separate institutions and Bagehot's contrasting of such separation with the hierarchy of parliamentary government, I showed that semi-presidentialism contains mixes of transaction and hierarchy in its formal design. Further, I showed that the precise nature of institutional juxtaposition in various semi-presidential systems suggests the value of recognizing two clear subtypes. In one, premierpresidential, the president has some role in the formation of governments (and perhaps other independent authority), but the cabinet depends on the exclusive confidence of the assembly. In the other, president-parliamentary, the cabinet is dually accountable to both the president and the assembly majority, though several newer examples impose limits on the assembly majority's authority to control the cabinet. The complexity of both of these subtypes of semi-presidential systems means that, as I noted above, the cabinet's selection and dismissal principals may differ, unlike in the pure types, where they are the same. Leveraging this feature, to which our attention is drawn by the neoMadisonian perspective outlined herein, could allow for some significant breakthroughs in our understanding of the performance of these systems. For instance, there is a vast and growing literature in comparative politics on cabinet formation, ${ }^{32}$ coalition termination, ${ }^{33}$ and presidential bargaining $v i s-\grave{a}$ vis the assembly and parties. ${ }^{34}$ However, most of it is focused on one or the other pure type. If semi-presidential systems are included, their mixing of authority patterns rarely is systematically incorporated into the analysis. Comparative parliamentary studies would be well advised to bring explicitly into their models a presidency that has actual powers over cabinet formation - as do Amorim Neto and Strøm (2006), who find that powerful presidencies have a discernible impact on the presence of nonpartisan cabinet ministers. Similarly, comparative presidential studies should extend beyond the Americas and include post-communist and African countries and a consideration of the potential impact of various forms of cabinet responsibility for various aspects of executive-legislative bargaining. Even better, cross-national studies that include countries of different institutional configurations should structure their analysis so as to allow tests of whether semi-presidentialism makes a difference. A promising example of this type of study is the one by Samuels and Hellwig (2005). Included among their rich findings is the conclusion that in semi-presidential systems, voters hold the president accountable for economic performance when the president and prime minister are politically compatible, but the prime minister's party when they are not (i.e. under cohabitation).

The neo-Madisonian perspective outlined herein allows us to see the ways in which details of the formal relationship of the cabinet to the president and the assembly, and the latter two to one another, change the balance of hierarchical 
subordination or transactional bargaining between institutions. In turn, these institutional details allow us to predict how actual relationships between constitutional actors is likely to shift in any given system depending on changes in the dynamics of party competition and organization. It is in these latter areas that the biggest breakthroughs in understanding these systems are likely to occur. By carefully understanding in a given system which factors are fixed (absent institutional reform) and which are transient (and thus dependent on election outcomes and leadership styles), we can get a firmer handle on how different democratic systems may evolve, as well as on which aspects of them might best be considered for institutional reform. The semi-presidential type has become, in the quarter century since Duverger's seminal piece, well established in political science and in the 'real world'; our understanding of it is likely to continue to advance in coming years.

\section{Acknowledgements}

I acknowledge the research assistance and advice of Royce Carroll and Mónica Pachón-Buitrago.

\section{Notes}

1 A non-exhaustive list of recent works in this subfield just in the past decade would include von Mettenheim (1997); Frye (1997, 2002); Taras (1997, 2003); Metclaf (2000); Siaroff (2003).

2 As is the president of Ireland, for example; also Finland since 2000 (Nousiainen, 2001)

3 The definition of parliamentary government deliberately is silent about the possibility of dissolution of the legislature, on which there is some variation. Dissolution is not logically required for the basic characteristics of parliamentarism to hold, but it is logically excluded by the basic defining characteristic of presidentialism.

4 This figure is adapted from a similar one in Lijphart $(1984,70)$.

5 The prime minister in such a system might also have the right to dissolve the assembly, but must then stand for reelection along with the assembly.

6 In Bolivia if a party list obtains a majority of votes, its head becomes president. Otherwise, and always in practice, congress selects as president the head of one of the top two (formerly three) lists. Bolivia and Switzerland are both often misclassified. For instance, both are 'semipresidential' to Gerring and Thacker (2004), but 'presidential' to Cheibub (2002), which is especially odd given the absence of any process in Switzerland by which an election can be definitive for selecting the executive.

7 Confusingly, Elgie (1999b, 13-14) classifies the Dominican Republic and Lebanon among cases deemed 'unambiguously' semi-presidential, yet the former lacks a prime minister and the latter lacks a popularly elected president.

8 Or even less as 'no doubt' a 'presidential government,' as Lijphart said in 1984 (p. 71), before the first experience of 'conhabitation' between a president of one ideological stripe and a cabinet of the other.

9 For surveys of contemporary principal-agent literature in political science and relations to the economics literature from which it derives, see Moe (1984) and Kiewiet and McCubbins (1991).

10 Of course, even for Britain and America, these descriptions are highly stylized. 
11 If there is a coalition cabinet, we could depict the principle locus of transactions as within the cabinet.

12 A president's appointment authority over cabinet ministers may be subject to a confirmation process by the assembly (as in the US Senate's 'advice and consent') or to censure by the assembly (as in Colombia since 1991). However, these assembly prerogatives are exercised oneby-one and do not rise to the level of subordination of the cabinet collectively to the assembly.

13 For an intellectual history of the concept of semi-presidentialism and its application, see Bahro Bayerlein, and Vesser (1998), and Elgie (1999a, b, 2004).

14 The fact that this transactional relationship, as well as the selecting authority of the president over the cabinet, are depicted as diagonal rather than horizontal reflects the mixing of hierarchy and transaction in the system that derives from the logic of a mixed constitutional design.

15 It therefore follows that any (hypothetical) system in which the president may dissolve parliament but the cabinet is not responsible to the assembly majority would work against the principle of checks and balances. The president in such a system would be highly 'powerful' but it does not follow that such a system would be more (or hyper- or super-) 'presidential,' if we conceptualize presidentialism (pure or semi-) as a system of mutual checks between elected agents of the electorate.

16 Consider the contrasting logic of dissolution in a parliamentary system, as well as the logical reason for not having dissolution in a presidential system: In a parliamentary system the assembly may be dissolved only by its own action or on the initiative of an agent of the assembly (i.e. the PM). In a presidential system, neither may dissolve the other, because both are agents of the people, not of each other.

17 For case selection, I surveyed all of the countries of 500,000 population or greater that were rated by Freedom House as at least 'partly free' 1990-1991 to 2004, or for each year since 2000, and then determined from a reading of their constitutions whether they were semi-presidential or not, by the definition used here. See also Shugart (2007).

18 It is not always straightforward from the constitution. I have relied on my best interpretation of constitutions and the secondary literature cited here (including country chapters in Elgie (1999a) and Taras (1997)); nonetheless, actual practice may differ in some cases from what I show.

19 For instance, whether the assembly can dismiss a cabinet only after it has been in place for a set period of time, or can dismiss only a limited number of cabinets per term.

20 The Polish constitution goes one step further, requiring that the no-confidence vote be 'constructive,' meaning that the majority, in initiating the cabinet's ouster, must simultaneously invest a new prime minister. Although this procedure makes it harder to remove a cabinet - a strictly negative vote will not suffice - and thus potentially permits the president greater leeway in the initial construction of a cabinet, it also makes the system more 'parliamentary' in that after a no-confidence vote, the president is sidelined in the process of installing a new government.

21 From 1982 to 2000 Sri Lanka was president-parliamentary, very similar to the Weimar configuration.

22 I do not consider here the power to call a referendum (see Metcalf (2000) and Roper (2002)). This power can be seen as more akin to dissolution power than to the veto in that it inserts the president, as the voters' agent, into the hierarchical relationship between the electorate and the assembly by referring directly to voters policy questions the assembly and cabinet may prefer to ignore.

23 Some parliamentary systems, such as in the Czech Republic and Greece, provide similar vetoes to their unelected presidents. The study of presidents in parliamentary systems has been relatively neglected; for studies that include them alongside semi-presidential systems see Shugart (1996), Baylis (1996), Amorim Neto and Strøm (2006), and my contribution (Chapter 10) in Budge et al. (1997). 
24 Georgia had a pure presidential system until after the 'Rose Revolution' of 2003.

25 The constitutional reforms in Ukraine that followed the mass demonstrations of the 'Orange Revolution' in late 2005 have shifted the system into the premier-presidential category (as shown in Table 1). See Christensen et al. (2005); I am grateful to Edward Rakhimkulov (personal communication) for supplying detailed information on constitutional changes that had yet to be translated. I remain responsible for any errors in interpretation of these materials.

26 See also Linz (1997, 10-13).

27 Suleiman (1994) makes a similar point about the French system.

28 For a related disagreement with the 'alternation' thesis, see Sartori (1994a, 124-125).

29 However, it is not clear how typical is one case on which this generalization is largely based: Moldova, where a political crisis ended in the abolition of the elected presidency.

30 For extensions of these themes, see Shugart (1999). Also related is Sartori's (1994b, 112-115) discussion of 'parliamentary-fit parties.'

31 The other two are parliamentary: Albania and Moldova (though, as noted, Moldova formerly was semi-presidential).

32 For reviews of this extensive literature, see Laver (1998), and Martin and Stevenson (2001).

33 As reviewed in Grofman and Van Roozendaal(1997), and Laver, 2003.

34 For example, Amorim Neto et al. (2003); Cheibub et al.(2004); Alemán and Tsebelis (2005).

\section{References}

Alemán, E. and Tsebelis, G. (2005) 'The origins of Presidential Conditional Agenda Setting', Latin American Research Review 40(2): 3-26.

Amorim Neto, O. and Strøm, K. (2006) 'Breaking the parliamentary chain of delegation: presidents and nonpartisan cabinet members in European democracies', British Journal Of Political Science 36(2) (forthcoming).

Amorim Neto, O., Cox, G.W. and McCubbins, M.D. (2003) 'Agenda power in Brazil's Câmara dos Deputados, 1989-1998', World Politics 55: 550-578.

Bagehot, W. (1867/1963) The English Constitution, London: Chapman and Hall.

Bahro, H., Bayerlein, B.H. and Vesser, E. (1998) 'Duverger's concept: Semi-presidential government revisited', European Journal of Political Research 34: 201-224.

Baylis, T. (1996) 'Presidents versus prime ministers: shaping executive authority in Eastern Europe', World Politics 48: 297-322.

Blondel, J (1984) 'Dual leadership in the contemporary world: a step towards regime stability?', in Dennis Kavanagh and Gillian Peele (eds.) Comparative Government and Politics: Essays in Honor of S.E. Finer, Boulder, Col.: Westview Press.

Budge, I., Newton, K., McKinley, R.D., Kirchner, E., Urwin, D., Armingeon, K., Muller-Rommel, F., Waller, M., Shugart, M., Nentwich, M., Kuhnle, S., Keman, H., Klingemann, H-.D. and Wessels, B. (1997) The Politics of the New Europe, Essex, UK: Addison Wesley Longman.

Carroll, R. and Shugart, M.S. (2005) 'Neo-Madisonian theories of Latin American institutions, in Gerardo Munck (ed.) Regimes and Democracy in Latin America, Volume 1: Theories and Agendas, New York: Oxford University Press, In press.

Chandler, A. (2001) 'Presidential veto power in post-communist Russia, 1994-1998', Canadian Journal of Political Science 34(3): 487-516.

Cheibub, J.A., Przeworski, A. and Saiegh, S. (2004) 'Government coalitions and legislative success under presidentialism and parliamentarism', British Journal of Political Science 34(4): 565-587.

Cheibub, J.A. (2002) 'Minority governments, deadlock situations, and the survival of presidential democracies', Comparative Political Studies 35(3): 284-312. 
Christensen, R.K., Rakhumkulov, E.R. and Wise, C.R. (2005) 'The Ukrainian Orange Revolution brought more than a new president: what kind of democracy will the institutional changes bring?' Communist and Post-Communist Studies 38: 207-230.

Duverger, M. (1980) 'A new political-system model: semi-presidential government', European Journal of Political Research 8(2): 165-187.

Elgie, R. (1999a) Semi-Presidentialism in Europe, Oxford: Oxford University Press.

Elgie, R. (1999b) 'The politics of semi-presidentialism', in Robert Elgie (ed.) Semi-Presidentialism in Europe, Oxford: Oxford University Press.

Elgie, R. (2004) 'Semi-presidentialism: concepts, consequences and contesting explanations', Political Studies Review 2: 314-330.

Frye, T. (1997) 'A politics of institutional choice: post-communist presidencies', Comparative Political Studies 30(5): 523-552.

Frye, T. (2002) 'Presidents, parliaments, and democracy: constitutional design, conflict management, and democracy, in A. Reynolds (ed) The Architecture of Democracy, Oxford: Oxford University Press.

Gerring, J. and Thacker, S. (2004) 'Political institutions and corruption: the role of unitarism and parliamentarism', British Journal of Political Science 34(2): 295-330.

Grofman, B. and Van Roozendaal, P. (1997) 'Modeling cabinet durability and termination', British Journal of Political Science 27: 419-451.

Hamilton, A., Madison, J., Jay, J. and Fairfield, R.P. (1787/1937) The Federalist Papers: A Collection of Essays Written in Support of the Constitution of the United States (from the original text of Alexander Hamilton, James Madison, John Jay) New York: Random House.

Helms, L. (2004) 'Five ways of institutionalizing political opposition: lessons from the advanced democracies', Government and Opposition 391 (Winter): 22-54.

Kiewiet, R. and McCubbins, M. (1991) The Logic of Delegation, Chicago, IL: University of Chicago Press.

King, A. (1976) 'Models of executive-legislative relations: Great Britain, France, and West Germany', Legislative Studies Quarterly 11 (February): 11-36.

Laver, M. (1998) 'Models of government formation', Annual Review of Political Science 1: 1-25.

Laver, M. (2003) 'Government termination', Annual Review of Political Science 6: 23-40.

Lijphart, A. (ed.) (1992) Parliamentary Versus Presidential Government, Oxford; New York: Oxford University Press.

Lijphart, A. (1984) Democracies: Patterns Of Majoritarian And Consensus Government In TwentyOne Countries, New Haven: Yale University Press.

Lijphart, A. (1999) Patterns of Democracy: Government Forms And Performance In Thirty-Six Countries, New Haven, Conn.: Yale University Press.

Linz, J.J. (1997) 'Introduction: some thoughts on presidentialism in postcommunist Europe, in Ray Tara (ed.) Postcommunist Presidents, Cambridge: Cambridge University Press.

Maddens, B. and Fiers, S. (2004) 'The direct PM election and the institutional presidentialisation of parliamentary systems', Electoral Studies 23(4 December): 769-793.

Martin, L.W. and Stevenson, R.T. (2001) 'Government formation in parliamentary democracies', American Journal of Political Science 45: 33-50.

Metcalf, L.K. (2000) 'Measuring presidential power', Comparative Political Studies 33(5): 661-685.

Mettenheim, Kurt von (1997) Presidential Institutions And Democratic Politics: Comparing Regional And National Contexts, Baltimore, MD; London: Johns Hopkins University Press.

Meyerson, R. (1999) 'Political economics and the Weimar disaster', Discussion Paper No. 1216, Center for Mathematical Studies in Economics and Mnagement Science, Northwestern University.

Moe, T.M. (1984) 'The new economics of organization', American Journal of Political Science 28: 739-777. 
Moe, T.M. and Caldwel, M. (1994) 'The institutional foundations of democratic government: a comparison of presidential and parliamentary systems', Journal of Institutional and Theoretical Economics 150(1): 171-195.

Mommsen, W.J. (1985) Max Weber and German politics, 1890-1920, Michael S. Steinberg (trans.), Chicago: University of Chicago Press.

Morgan-Jones, E. and Schleiter, P. (2004) 'Governmental change in a president-parliamentary regime: the case of Russia 1994-2003', Post-Soviet Affairs 20(2): 132-163.

Müller, W.C. (1999) 'Austria, in Robert Elgie (ed.) Semi-Presidentialism in Europe, Oxford: Oxford University Press.

Noble, G.W. (1999) 'Opportunity lost: partisan incentives and the 1997 constitutional revisions in Taiwan', China Journal 41(January): 89-114.

Nousiainen, J. (2001) 'From semi-presidentialism to parliamentary government: political and constitutional developments in Finland', Scandinavian Political Studies 24(2): 95-109.

Palmer, M.S. (1995) 'Toward an economics of comparative political organization: examining ministerial responsibility', Journal of Law, Economics and Organization 11(1): 164-188.

Parrish, S. (1998) 'Presidential decree authority in Russia, 1991-1995, in J. Carey and M. S. Shugart (eds.) Executive Decree Authority, Cambridge: Cambridge University Press.

Protsyk, O. (2003) 'Troubled semi-presidentialism: stability of the constitutional system and cabinet in Ukraine', Europe-Asia Studies 55(7): 1077-1095.

Protsyk, O. (2004) 'Ruling with decrees: presidential decree making in Russia and Ukraine', Europe-Asia Studies 565 (July): 637-660.

Redslob, R. (1918) Die parlamentarische Regierung in ihrer wahren und unechten Form: Eine vergleichende Studie über die Verfassungen von England, Belgien, Ungarn, Schweden und Frankreich, [The parliamentary government in its true and its false form - A comparative study on the constitutions of England, Belgium, France, Hungary, Sweden and France]. Tübingen: J.C.B. Mohr.

Remington, T.F., Smith, S.S. and Haspel, M. (1998) 'Decrees, laws, and inter-branch relations in the Russian federation', Post-Soviet Affairs 14: 301-315).

Rigger, S. (2002) 'The education of Chen Shui-bian: Taiwan's experience of divided government', Journal of Contemporary China 11(33): 613-624.

Roper, S.D. (2002) 'Are all semipresidential regimes the same?' A comparison of premier-presidential regimes. Comparative Politics 34(3): 253-272.

Samuels, D. and Hellwig, T. (2005) Democratic Regimes and Electoral Accountability around the World Paper presented at the annual meeting of the American Political Science Association, Washington, DC.

Sartori, G. (1994b) 'Neither presidentialism nor parliamentarism', in Arturo Valenzuela. (eds.) The Failure of Presidential Democracy, Vol. 1: Comparative Perspectives, Juan J. Linz and Baltimore: Johns Hopkins University Press.

Sartori, G. (1994a) Comparative Constitutional Engineering: An Inquiry Into Structures, Incentives And Outcomes, Basingstoke: Macmillan.

Shugart, M.S. (1996) 'Executive-legislative relations in post-communist Europe', Transition 13(December 1996): 6-11.

Shugart, M.S. (1999) 'Presidentialism, parliamentarism and the provision of collective goods in less-developed countries', Constitutional Political Economy 10(1): 53-88.

Shugart, M.S. (2007) 'Comparative executive-legislative relations', in R.A.W. Rhodes, Sarah Binder, and Bert Rockman (eds.) Oxford Handbook of Political Institutions, Oxford: Oxford University Press, (in press).

Shugart, M.S. and Carey, J.M. (1992) Presidents and Assemblies: Constitutional Design and Electoral Dynamics, Cambridge: Cambridge University Press. 
Siaroff, A. (2003) 'Comparative presidencies: the inadequacy of the presidential, semi-presidential and parliamentary distinction', European Journal of Political Research 42(3): 287-312.

Stirk, P. (2002) 'Hugo Preuss, german political thought and the Weimar constitution', History of Political Thought 23(3): 497-516.

Suleiman, E.N. (1994) 'Presidentialism and Political Stability in France', in J.J. Linz and A. Valenzuela (ed.) The Failure of Presidential Democracy, Vol. 1: Comparative Perspectives, Baltimore: Johns Hopkins University Press.

Talat-Kelpsa, L. (2001) 'The presidency and democratic consolidation in Lithuania', Journal of Baltic Studies 32(2): 156-169.

Taras, R. (2003) 'Executive leadership: presidents and governments. In S. White and Judy Batt a Paul G. Lewis, (eds.) Developments in Central and Eastern European Politics 3, Houndmills, Basingstoke: Macmillan, pp 115-132.

Taras, R. (ed.) (1997) Postcommunist Presidents, Cambridge; New York: Cambridge University Press.

Weber, M. (1917/1978) 'Parliament and Government in a Reconstructed Germany', in R. Guenther and C. Wittich (eds.) Economy and Society: An Outline of Interpretive Sociology, California: California University Press, Vol. 2. 